\title{
Rates of myogenesis and myofiber numbers are reduced in late gestation IUGR fetal sheep
}

\author{
Eileen I Chang1, Paul J Rozance', Stephanie R Wesolowski', Leanna M Nguyen ${ }^{1}$, Steven C Shaw', Robert A Sclafani ${ }^{2}$, \\ Kristen K Bjorkman ${ }^{3}$, Angela K Peter ${ }^{3}$, William W Hay Jr' ${ }^{1}$ and Laura D Brown'1
}

1Department of Pediatrics, University of Colorado School of Medicine, Perinatal Research Center, Aurora, Colorado, USA 2Department of Biochemistry and Molecular Genetics, University of Colorado School of Medicine, Aurora, Colorado, USA ${ }^{3}$ Department of Molecular, Cellular and Developmental Biology and BioFrontiers Institute, University of Colorado Boulder, Boulder, Colorado, USA

Correspondence should be addressed to L D Brown: Laura.Brown@ucdenver.edu

\begin{abstract}
Intrauterine growth-restricted (IUGR) fetuses are born with reduced skeletal muscle mass. We hypothesized that reduced rates of myogenesis would contribute to fewer and smaller myofibers in IUGR fetal hindlimb muscle compared to the normally growing fetus. We tested this hypothesis in IUGR fetal sheep with progressive placental insufficiency produced by exposing pregnant ewes to elevated ambient temperatures from 38 to 116 days gestation ( $d G A$; term $=147 \mathrm{dGA}$ ). Surgically catheterized control $(C O N, n=8)$ and IUGR ( $n=13)$ fetal sheep were injected with intravenous 5-bromo-2'deoxyuridine (BrdU) prior to muscle collection (134 dGA). Rates of myogenesis, defined as the combined processes of myoblast proliferation, differentiation, and fusion into myofibers, were determined in biceps femoris (BF), tibialis anterior (TA), and flexor digitorum superficialis (FDS) muscles. Total myofiber number was determined for the entire cross-section of the FDS muscle. In IUGR fetuses, the number of $\mathrm{BrdU}^{+}$myonuclei per myofiber cross-section was lower in $\mathrm{BF}, \mathrm{TA}$, and FDS $(P<0.05)$, total myonuclear number per myofiber cross-section was lower in BF and FDS $(P<0.05)$, and total myofiber number was lower in FDS $(P<0.005)$ compared to CON. mRNA expression levels of cyclins, cyclin-dependent protein kinases, and myogenic regulatory factors were lower $(P<0.05)$, and inhibitors of the cell cycle were higher $(P<0.05)$ in IUGR BF compared to CON. Markers of apoptosis were not different in IUGR BF muscle. These results show that in IUGR fetuses, reduced rates of myogenesis produce fewer numbers of myonuclei, which may limit hypertrophic myofiber growth. Fewer myofibers of smaller size contribute to smaller muscle mass in the IUGR fetus.
\end{abstract}

Journal of Endocrinology (2020) 244, 339-352

\section{Introduction}

Two distinct phases of myogenesis in utero establish fetal skeletal muscle mass. After the scaffold of primary myofibers is established during the embryonic period, secondary myogenesis occurs from the proliferation and fusion of fetal myoblasts to increase myofiber number during mid-gestation (Lee et al. 2013).
Total myofiber number is established prior to birth, as has been demonstrated in mice (Rowe \& Goldspink 1969), piglets (Wigmore \& Stickland 1983), sheep (Fahey et al. 2005b), and humans (Widdowson et al. 1972). Myogenesis continues to support muscle hypertrophic growth by adding myonuclei to existing secondary myofibers 
during late gestation and into early postnatal life (Moss \& Leblond 1971, White et al. 2010, Gokulakrishnan et al. 2017). Slower rates of myogenesis and/or fewer myoblasts entering the cell cycle in utero can have lasting effects on muscle mass throughout the lifespan by both reducing the number and size of myofibers.

Several factors regulate fetal myogenesis, including insulin, IGFs, nutrients, and oxygen availability (Brown 2014). Conditions in human pregnancy that reduce nutrient and oxygen delivery to the fetus, such as placental insufficiency, result in an intrauterine growth-restricted (IUGR) fetus with less muscle mass than in normally growing fetuses (Padoan et al. 2004). A particularly relevant sheep model of placental insufficiency and IUGR produced by exposing pregnant ewes to elevated ambient temperatures mimics the human IUGR condition with 'fetal brain sparing' at the expense of the growth of skeletal muscle and splanchnic organs (Bell et al. 1987, Galan et al. 1999). In this model, placental insufficiency begins early in gestation and is progressive (Arroyo et al. 2008), such that nutrient and oxygen restriction to the fetus occurs concurrently with the period of secondary myogenesis (Du et al. 2010, Lee et al. 2013, Brown 2014). By late gestation, fetal muscle weights relative to fetal body weight, in vivo muscle protein fractional synthetic rates, muscle protein accretion rates, and myofiber cross-sectional areas are lower compared to normally growing fetal lambs, indicating impaired hypertrophic growth of the myofiber (Yates et al. 2016, Rozance et al. 2018). In addition, fetal myoblasts within muscle crosssections collected from IUGR muscle at late gestation express less proliferating cell nuclear antigen (PCNA), Ki-67, and myogenin, indicating that fewer myoblasts are undergoing proliferation and differentiation (Yates et al. 2014, Soto et al. 2017). Whether reduced rates of fetal myogenesis, as defined by the process of myoblast proliferation, differentiation, and fusion into myofibers in vivo, contribute to reduced myofiber number, myonuclear number, and slower hypertrophic myofiber growth in the IUGR fetus has not been determined.

In this study, we tested the hypothesis that rates of myogenesis are reduced in the IUGR fetus. This was accomplished using 5-bromo-2'-deoxyuridine (BrdU), which is a thymidine analog that is selectively incorporated into cellular DNA during the synthesis (S) phase of the cell cycle. BrdU was intravenously infused into late gestation control and IUGR fetal sheep to trace the number of myoblasts that had proliferated, differentiated, and fused into the myofiber to become myonuclei during the labeling period. To further define the cellular processes in skeletal muscle that might be impacted by placental insufficiency, we measured mRNA expression of myogenesis regulators in fetal muscle biopsies. We determined the expression of the primary regulators of cell cycle progression, including cyclins, cyclin-dependent protein kinases (CDKs), and cell cycle inhibitors. To determine whether IUGR increased rates of cell death, we measured the mRNA expression of genes that regulate apoptosis and the protein expression of cleaved caspase 3 . We also measured the mRNA expression of muscle regulatory factors and other myokines known to regulate myoblast differentiation, including myostatin and irisin. Finally, we measured myonuclear number per myofiber and the total number of myofibers at the level of the mid-belly of the flexor digitorum superficialis (FDS) hindlimb muscle to determine whether lower rates of myogenesis earlier in gestation produced overall fewer numbers of myofibers with fewer myonuclei and thus the decreased muscle mass that is characteristic of the IUGR fetus.

\section{Materials and methods}

\section{Animal care, surgical procedure, and study design}

Pregnant Columbia-Rambouillet mixed-breed sheep were studied at the University of Colorado Perinatal Research Center using protocols approved by the Institutional Animal Care and Use Committee (\#77617(10)1E). The Perinatal Research Center is accredited by the American Association for the Accreditation of Laboratory Animal Care (AAALAC) International. Pregnant sheep were randomly assigned to either an environmental chamber that exposed sheep to temperatures that cycled between $40^{\circ} \mathrm{C}$ and $35^{\circ} \mathrm{C}$ every $12 \mathrm{~h}$ with $35-40 \%$ humidity from 38 to 116 days gestation (dGA, term $=147 \mathrm{dGA}$ ) to produce placental insufficiency and intrauterine growth restriction (IUGR group; $n=13$ ) (Bell et al. 1987, Rozance et al. 2018) or to an environmental chamber at $21^{\circ} \mathrm{C}$ for $24 \mathrm{~h}$ with $35-40 \%$ humidity from 43 to 120 dGA (CON group; $n=8$ ). In the environmental chambers, sheep were kept in individual pens alongside other sheep. After environmental treatment, all sheep were housed in normal ambient temperatures and humidity for the remainder of the studies. All sheep were given ad libitum access to water. Maternal feed intake was similar between sheep in CON and IUGR groups (Rozance et al. 2018). Fetuses in the study were all singletons except for one triplet fetus in the IUGR group. The triplet fetus (fetal weight: $1466 \mathrm{~g}$ ) was included in the analysis because it was not an outlier 
for any physiological or anthropometric parameters measured within the IUGR group.

A schematic of the study design is show in Fig. 1. Late gestation pregnant sheep underwent a surgical procedure for fetal and maternal vascular catheter placement according to methods previously published (Rozance et al. 2018). Briefly, sheep were fasted for $24 \mathrm{~h}$ and thirsted for $12 \mathrm{~h}$ prior to surgery. A superficial maternal vein was used to administer diazepam $(0.2 \mathrm{mg} / \mathrm{kg})$ and ketamine $(20 \mathrm{mg} / \mathrm{kg}$ ) and sheep were maintained on isoflurane inhalation anesthesia (2-4\%) for the surgical procedure. The fetal lamb was exposed by maternal laparotomy and hysterotomy. Catheters were placed in the external iliac artery, the distal inferior vena cava, and the external iliac vein. A 3-mm transit time ultrasonic blood flow transducer was positioned around the external iliac artery. The catheters and flow probe were tunneled subcutaneously to the maternal flank. Sheep recovered for a minimum of 6 days after surgery. A metabolic study performed on the day of muscle collection included hindlimb blood flow, substrate uptake rates by the hindlimb, arterial plasma hormone concentrations, and protein metabolic rates, and those results were previously published (Rozance et al. 2018). Fetal plasma arterial insulin, IGF-1, and cortisol concentrations were measured by an ELISA as described previously (Soto et al. 2017). Plasma norepinephrine concentrations were measured using HPLC as described previously (Brown et al. 2012).

Twenty-four hours prior to muscle collection, a dose of BrdU (Sigma-Aldrich) diluted in $0.9 \% \mathrm{NaCl}$ was administered by IV bolus directly into the fetus at a dose of $20 \mathrm{mg} / \mathrm{kg}$ estimated fetal weight. The dose was repeated

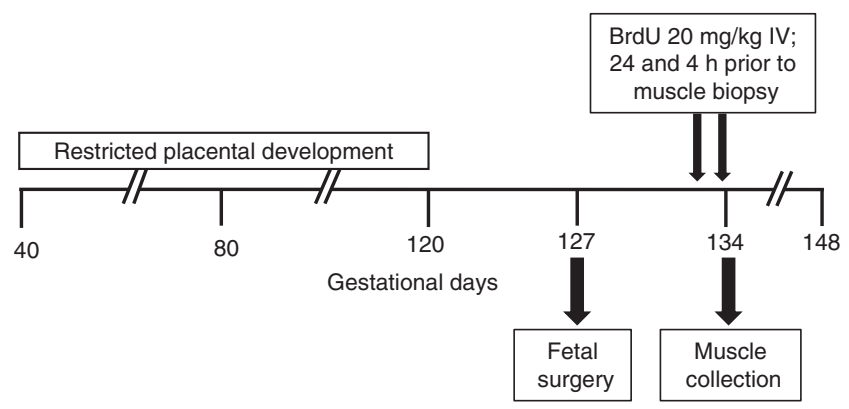

\section{Figure 1}

Schematic design. Pregnant sheep were housed in an environmental chamber with elevated temperatures $\left(40^{\circ} \mathrm{C}\right.$ for $12 \mathrm{~h} ; 35^{\circ} \mathrm{C}$ for $12 \mathrm{~h}$; $35-40 \%$ humidity) for 70 days of gestation to produce placental insufficiency and IUGR. Control pregnant sheep were housed in an environmental chamber $\left(21^{\circ} \mathrm{C}\right.$ for $24 \mathrm{~h}$; $35-40 \%$ humidity) for the same number of days. Six days after fetal vascular catheters were surgically placed, BrdU was administered directly to the fetus by intravenous (IV) bolus injection $24 \mathrm{~h}$ and $4 \mathrm{~h}$ prior to muscle biopsy.

(c) 2020 Society for Endocrinology Published by Bioscientifica Ltd. Printed in Great Britain
$4 \mathrm{~h}$ prior to muscle collection to ensure that the presence of BrdU was maintained throughout the entire 24-h dosing period. The dose and timing of BrdU bolus administration was determined based on previous publications (Shah et al. 1997, Greenwood et al. 1999b, Herdrich et al. 2010, Yu et al. 2015, Gokulakrishnan et al. 2017).

\section{Fetal skeletal muscle collection}

After conclusion of the metabolic study, ewes received diazepam (0.2 $\mathrm{mg} / \mathrm{kg})$ and ketamine $(20 \mathrm{mg} / \mathrm{kg})$ intravenously and fetuses were delivered via maternal laparotomy and hysterotomy. The biceps femoris muscle was exposed and a biopsy was obtained from the anesthetized fetus and immediately frozen in liquid nitrogen for RNA and protein analysis. Intravenous pentobarbital sodium (Fatal Plus; Bortech Parmaceuticals, Dearborn, MI, USA) was administered to both the mother and the fetus, after which the fetus was weighed. The biceps femoris (BF), FDS, and tibialis anterior (TA) in the fetal hindlimb were weighed. Portions of the BF and TA mid-bellies and the entire cross-section of the FDS midbelly were placed on corkboard thinly coated with optimal cutting temperature media, frozen in liquid nitrogencooled isopentane for $60 \mathrm{~s}$, and stored at $-80^{\circ} \mathrm{C}$.

\section{Immunohistochemistry}

\section{BrdU immunostaining}

Cryopreserved BF, TA and FDS muscles were sectioned $(10 \mu \mathrm{m})$ as previously described (Brown et al. 2016). All antibodies used in this study were diluted in Permeabilization/Blocking Solution (P/BS; phosphate buffered saline, $0.01 \% \mathrm{v} / \mathrm{v}$ Triton X-100, 0.12\% w/v BSA, $0.12 \% \mathrm{w} / \mathrm{v}$ non-fat dry milk) with $5 \%$ normal goat serum. Sections were incubated with anti-BrdU rat monoclonal IgG2a (1:400; Abcam), anti-dystrophin mouse monoclonal IgG2b (1:250; MANDRA1, Developmental Studies Hybridoma Bank, Iowa City, IA, USA), and counterstained with DAPI nuclear stain (1:1000; Sigma-Aldrich). Primary antibodies were detected with goat anti-rat polyclonal IgG conjugated to Alexa Fluor 568 (1:500; Thermo Fisher Scientific) and donkey anti-mouse polyclonal IgG $(\mathrm{H}+\mathrm{L})$ conjugated to Cy2 (1:250; Jackson ImmunoResearch Laboratories, Inc.). Images were quantified using the Count and Measure module within the CellSens Dimension Imaging Software (Olympus America, Inc.). For each muscle type, two sections were analyzed with a minimum of 1000 fibers per section. BrdU+ nuclei were expressed as a ratio to total nuclei to determine the BrdU labeling index 
among all cell types within muscle. DAPI-stained nuclei within the dystrophin-stained sarcolemma were classified as myonuclei. BrdU+ nuclei within the sarcolemma represented myoblasts that underwent proliferation, differentiation, and fusion to become myonuclei (Fig. 2A). Therefore, the number of $\mathrm{BrdU}^{+}$myonuclei normalized to either total myonuclei or myofiber number within a section represented the rate of myogenesis, or myoblast proliferation, differentiation, and fusion, during the BrdU labeling period. The total number of myonuclei per fiber cross-section was calculated to determine myonuclear number.

\section{Total myofiber number and myonuclear domain quantification}

The FDS muscle was used to determine total myofiber number because it is encased in fascia, thus allowing for clear delineation of the cross-sectional borders of the muscle mid-belly. The FDS muscle at mid-belly was incubated with anti-laminin rabbit polyclonal IgG (1:100, Sigma-Aldrich) and anti-dystrophin mouse monoclonal IgG2b (1:250). Primary antibodies were detected with goat anti-rabbit conjugated to Alexa Fluor® 488 (1:250; Thermo Fisher Scientific) and donkey anti-mouse polyclonal IgG conjugated to Cy2 (1:250). The entire section was imaged (Fig. 3A) and particle analyzer function (ImageJ, US National Institutes of Health) was used to quantify the total myofiber number, total area of the section composed of myofibers, and average myofiber area. In ImageJ, the FDS images were converted into an 8-bit binary image (i.e. 256 shades of gray), and a standard minimum (0 gray scale level) and maximum (4-9 gray scale levels) threshold was manually set to exclude non-fibers and was applied uniformly across all images. The myonuclear domain, or the cytoplasmic area per myonucleus, was calculated by dividing the average myofiber area by the number of myonuclei per myofiber cross-section in the FDS muscle.

\section{RNA analysis}

RNA was extracted from BF muscle (100 mg) using TRIzol LS (Invitrogen) and homogenization. To separate nucleic acids and proteins, the homogenate was mixed with chloroform and centrifuged at $12,000 \mathrm{~g}$ at $4^{\circ} \mathrm{C}$ for $15 \mathrm{~min}$.
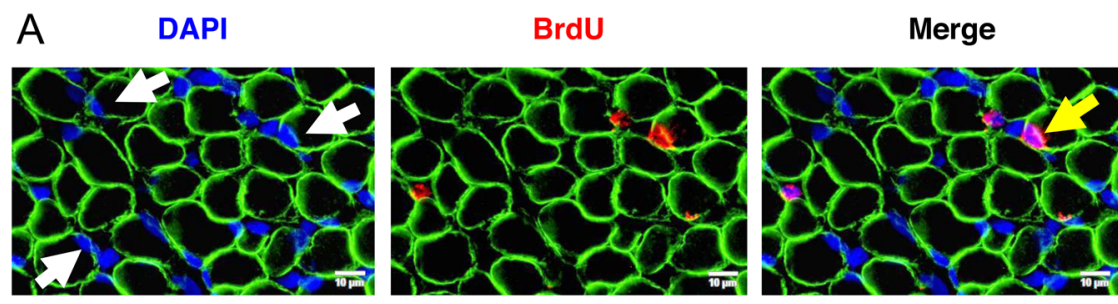

B

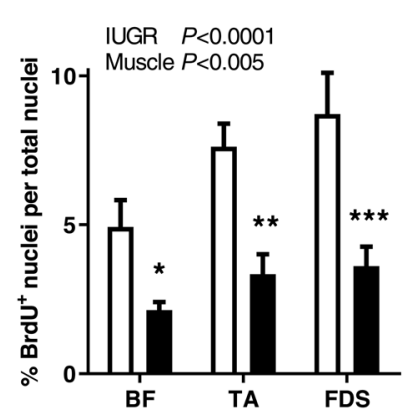

D

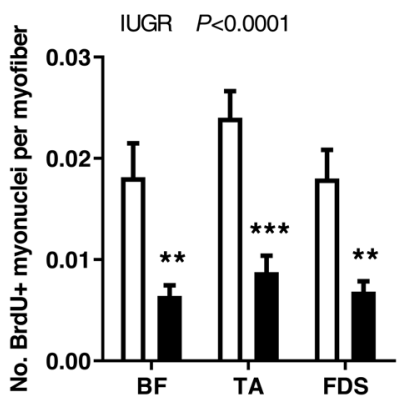

C

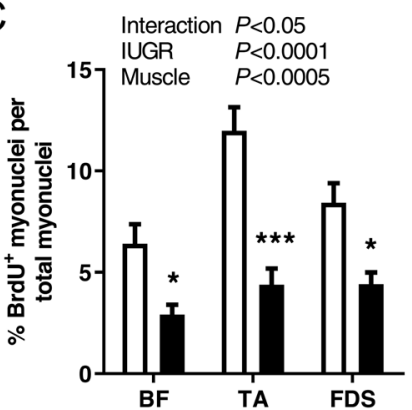

E

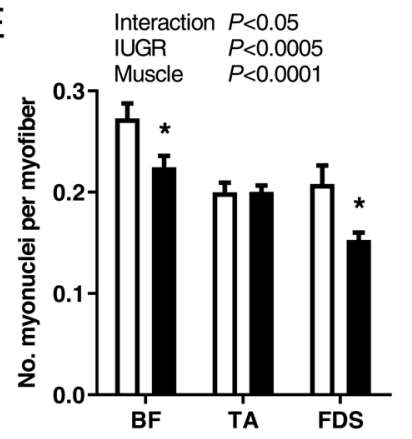

Figure 2

BrdU immunostaining. (A) Representative sections of biceps femoris (BF) muscle showing myofiber plasma membrane (anti-dystrophin, green), nuclei (DAPI, blue), and BrdU+ nuclei (anti-BrdU, red). Myonuclei within the confines of the myofiber and $\mathrm{BrdU}^{+}$myonuclei are identified by white and yellow arrows, respectively. Results are shown for (B) BrdU labeling index, (C) percent of $\mathrm{BrdU}^{+}$ myonuclei per total myonuclei, (D) number of $\mathrm{BrdU}^{+}$myonuclei per myofiber cross-section, and (E) myonuclei per myofiber cross-section in $\mathrm{BF}$, tibialis anterior (TA), and flexor digitorum superficialis (FDS) muscles from CON (white bar, $n=8$ ) and IUGR (black bar, $n=12$ ) fetuses. Values represent mean \pm S.E.M. Two-way ANOVA results are shown; $* P<0.05, * \star P<0.005, * \star \star P<0.0005$ by Bonferroni post-hoc test comparisons. 

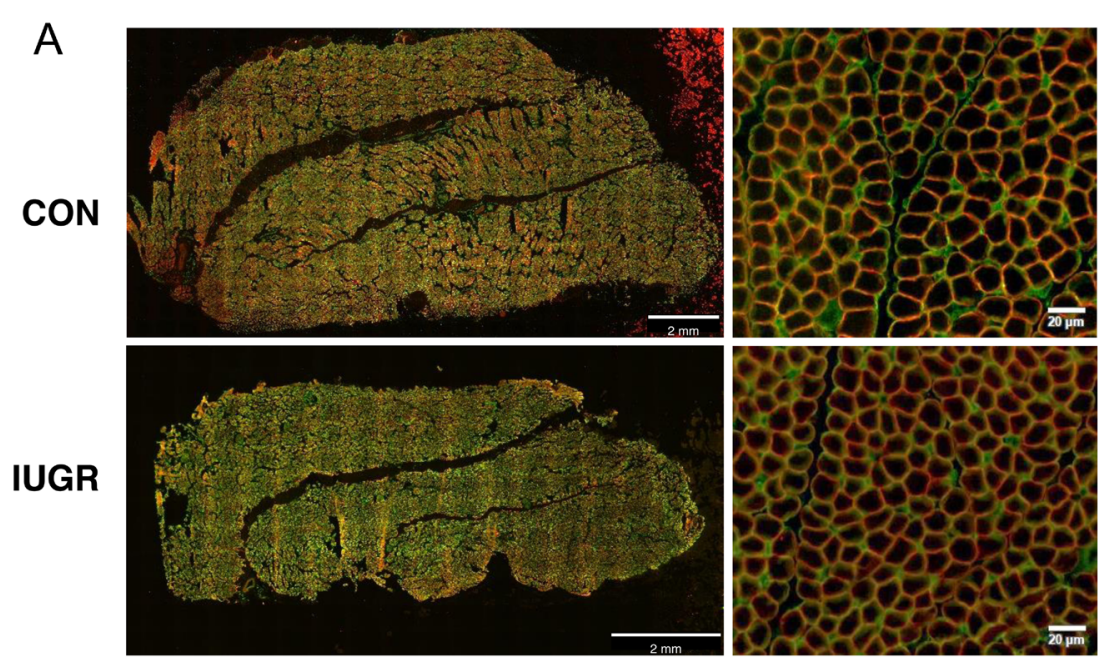
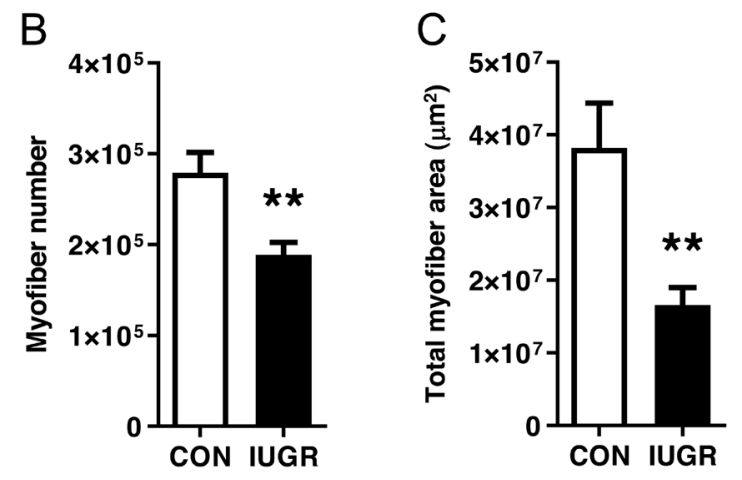

The aqueous phase was removed, and total RNA was isolated using RNeasy Mini Kit (Qiagen). Quantity of RNA was determined with a spectrophotometer (Nanodrop 1000). RNA ( $2 \mu \mathrm{g})$ was reverse transcribed using Superscript III and Oligo dT $18-20$ (Invitrogen) at $50^{\circ} \mathrm{C}$ for $1 \mathrm{~h}$. Real time PCR (Lightcycler 480 II; Roche Life Science) on a 1:10 dilution was performed in triplicate using standard curves for relative quantification between groups as previously described (Benjamin et al. 2017). Primers were developed and validated for all real-time PCR assays and are either previously published (Soto et al. 2017) or shown in Table 1. mRNA expression was normalized to the average of three reference genes: ACTIN, S15, and RPL37A.

\section{Protein analysis}

Biopsies of BF collected from the anesthetized fetus were powdered using mortar and pestle and incubated for $1 \mathrm{~h}$ at $4^{\circ} \mathrm{C}$ in lysis buffer $(20 \mathrm{mM}$ Tris- $\mathrm{HCl}, 150 \mathrm{mM}$ $\mathrm{NaCl}, 2 \mathrm{mM}$ EDTA, $2.5 \mathrm{mM}$ Na pyrophosphate, $20 \mathrm{mM}$ $\mathrm{NaF}$ ) with $0.004 \% \mathrm{v} / \mathrm{v}$ phosphatase inhibitor II/III and $0.01 \% \mathrm{v} / \mathrm{v}$ protease inhibitor (Sigma-Aldrich). Lysate was homogenized using a probe sonicator (VC50 Vibra-Cell;

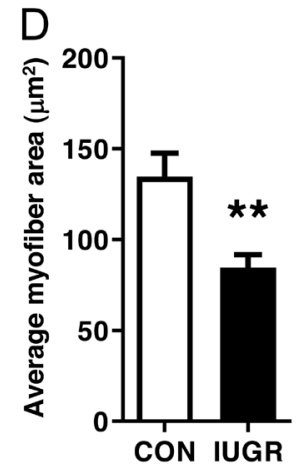

\section{Figure 3}

Myofiber number. (A) Representative sections of flexor digitorum superficialis (FDS) muscle showing the basal lamina (anti-laminin, green) and myofiber plasma membrane (anti-dystrophin, red). (B) Total number of myofibers, (C) total area occupied by myofibers in the muscle crosssection, and (D) average size of individual myofibers in FDS muscle from CON (white bar, $n=8$ ) and IUGR (black bar, $n=12$ ) fetuses. Values represent mean \pm S.E.M. ${ }^{* *} P<0.005$ by Student's t-test.

Sonics and Materials, Danbury, CT, USA) and then centrifuged at $17,000 \boldsymbol{g}$ at $4^{\circ} \mathrm{C}$ for $30 \mathrm{~min}$ and supernatant was stored at $-80^{\circ} \mathrm{C}$. Protein quantification, gel electrophoresis, and transfer to nitrocellulose membranes was performed in duplicate as previously described (Brown et al. 2009). Membranes were incubated with primary rabbit polyclonal IgG antibodies p130 and caspase 3 (1:1000 in Tris-buffered saline (TBS) with $0.1 \%$ v/v Tween 20 and 5\% w/v BSA; Cell Signaling Technology). Actin mouse monoclonal IgG (1:10,000; MP Biomedicals, Santa Ana, CA, USA) was used as a loading control.

For nuclear enrichment preparations from the BF, Thermo Scientific NE-PER Nuclear and Cytoplasmic Extraction Reagents were used per manufacture protocol (Product \# 78835). Protein (15 $\mu$ g) was separated by gel electrophoresis and transferred to membranes and blocked as previously described (Brown et al. 2016). Membranes were incubated with primary rabbit monoclonal IgG antibody p21 (1:1000 in TBS with $0.1 \% \mathrm{v} / \mathrm{v}$ Tween 20 and 5\% w/v BSA; Cell Signaling Technology). Lamin C (1:1000; Millipore) was used to verify nuclear extraction and to control for loading differences. 

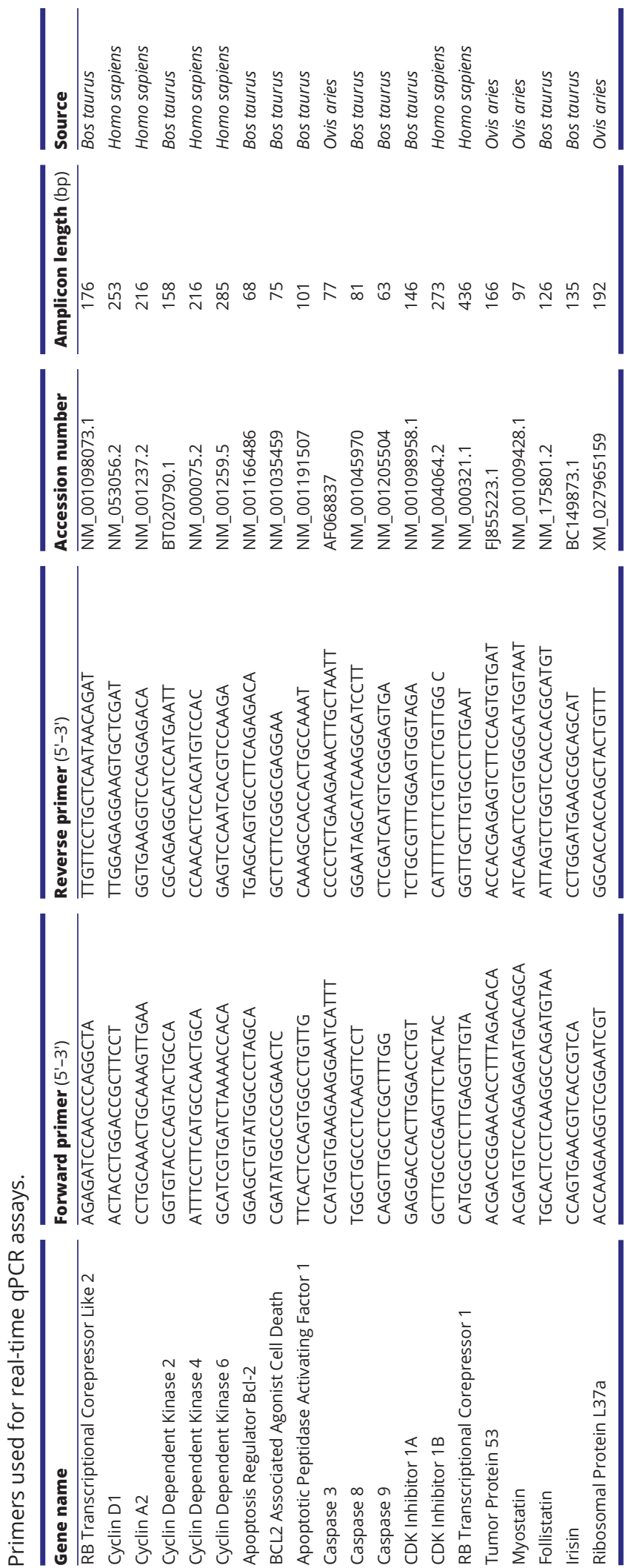

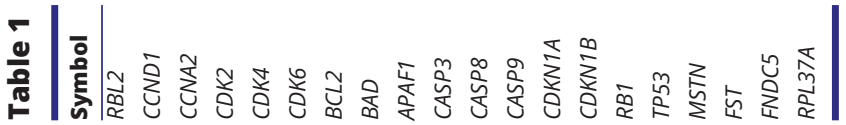

(c) 2020 Society for Endocrinology Published by Bioscientifica Ltd. Printed in Great Britain

\section{Statistical analysis}

The study was not designed a priori to measure differences between sexes; thus, determination of sex differences was limited to screening for a fixed effect of sex for each variable, and none were significant. A Student's t-test or MannWhitney test was used when CON and IUGR groups were compared directly (Prism 6, GraphPad Software). If the analysis was performed among different muscle types within the fetal hindlimb, a two-way ANOVA was used to determine the main effects of group (CON, IUGR) and muscle type (FDS, TA, BF), and their interaction. Bonferroni post hoc test was performed to determine the differences among groups. Correlations between circulating hormones and BrdU-labeled myonuclei and/or myofiber number were determined using Pearson's correlation. Correlations were determined for all fetuses pooled, as variability in both hormone concentrations and myogenesis rates also could be related to muscle size in CON as well as IUGR fetuses. Norepinephrine, insulin, and IGF-1 were log transformed for correlation analysis. $P<0.05$ was considered statistically significant.

\section{Results}

\section{Fetal weights and physiological parameters}

Physiological measurements of fetuses included in this study have been previously published (Rozance et al. 2018) but are shown in Table 2 for completeness. IUGR fetuses had lower body weights $(P<0.0005)$ and lower hindlimb BF $(P<0.0001)$, TA $(P<0.0005)$, and FDS $(P<0.0005)$ muscle weights compared to CON fetuses at 134 dGA. Arterial plasma glucose concentrations and blood oxygen content, $\mathrm{pH}, \mathrm{P}_{\mathrm{a}} \mathrm{O}_{2}$, and $\mathrm{S}_{\mathrm{a}} \mathrm{O}_{2} \%$ were lower in IUGR fetuses compared to CON $(P<0.05)$. Circulating plasma insulin $(P<0.005)$ and IGF-1 $(P<0.005)$ concentrations were lower and norepinephrine concentrations were higher $(P<0.005)$ in IUGR fetuses compared to CON (Table 2$)$.

\section{Myogenesis in vivo}

The BrdU dose was administered based on an estimated fetal weight at the time of surgery. Because fetal weight in the IUGR group was over-estimated, IUGR fetuses received a larger dose per $\mathrm{kg}$ than $\mathrm{CON}$ based on actual weight at the time of animal necropsy (IUGR: $23.3 \pm 1.5$ vs CON: $18.3 \pm 0.7 \mathrm{mg} / \mathrm{kg} / \mathrm{dose} ; \quad P<0.05)$. Despite receiving a higher dose of BrdU per $\mathrm{kg}$, the BrdU labeling index, or the ratio of $\mathrm{BrdU}^{+}$nuclei per total nuclei, was lower in BF $(P<0.05)$, TA $(P<0.005)$, and FDS $(P<0.0005)$ 
Table 2 Fetal weights and physiological measurements.

\begin{tabular}{l}
\hline \\
\hline Gestational age (days) \\
Male fetus (\%) \\
Fetal weight (kg) \\
Biceps femoris (BF; g) \\
Tibialis anterior (TA; g) \\
Flexor digitorum superficialis (FDS; g) \\
Fetal blood gas measurements \\
Blood $\mathrm{O}_{2}$ content (mM) \\
Blood pH \\
Blood $\mathrm{P}_{\mathrm{a}} \mathrm{CO}_{2}(\mathrm{mmHg})$ \\
Blood $\mathrm{P}_{\mathrm{a}} \mathrm{O}_{2}(\mathrm{mmHg})$ \\
Blood $\mathrm{Hgb}(\mathrm{mM})$ \\
$\mathrm{S}_{\mathrm{a}} \mathrm{O}_{2}(\%)$ \\
Fetal arterial plasma substrate and hormone concentrations \\
Glucose $(\mathrm{mM})$ \\
Lactate $(\mathrm{mM})$ \\
Insulin $(\mathrm{ng} / \mathrm{mL})$ \\
IGF-1 $(\mathrm{ng} / \mathrm{mL})$ \\
Cortisol $(\mathrm{ng} / \mathrm{mL})$ \\
Norepinephrine (pg/mL)
\end{tabular}

\begin{tabular}{c}
\hline Control \\
\hline $134.4 \pm 0.4$ \\
50 \\
$3.3 \pm 0.1$ \\
$18.1 \pm 0.7$ \\
$4.0 \pm 0.3$ \\
$3.1 \pm 0.3$ \\
$3.3 \pm 0.2$ \\
$7.4 \pm 0.0$ \\
$50.4 \pm 0.7$ \\
$20.6 \pm 0.7$ \\
$6.9 \pm 0.2$ \\
$48.3 \pm 1.8$ \\
$1.0 \pm 0.3$ \\
$2.0 \pm 0.1$ \\
$0.40 \pm 0.09$ \\
$108.2 \pm 15.2$ \\
$20.2 \pm 5.3$ \\
$617 \pm 253$
\end{tabular}

\begin{tabular}{c}
\hline IUGR \\
\hline $134.1 \pm 0.3$ \\
50 \\
$2.0 \pm 0.2$ \\
$9.9 \pm 1.0$ \\
$2.1 \pm 0.3$ \\
$1.6 \pm 0.2$ \\
$1.9 \pm 0.3$ \\
$7.3 \pm 0.0$ \\
$51.5 \pm 0.7$ \\
$14.6 \pm 0.9$ \\
$6.9 \pm 0.3$ \\
$26.6 \pm 3.2$
\end{tabular}

\begin{tabular}{c}
\hline P value \\
\hline 0.5 \\
$<0.0005$ \\
$<0.0001$ \\
$<0.0005$
\end{tabular}

Values are means \pm S.E.M. Control $n=8$; IUGR $n=13$. $P$ values from Student's $t$-tests or Mann-Whitney test are shown.

aStatistical analysis on log-transformed values. Data from this cohort of animals were previously published (Rozance et al. 2018).

IUGR muscle compared to CON (Fig. 2B). To assess the rate of myogenesis, we counted the number of nuclei that were $\mathrm{BrdU}^{+}$and resided within the sarcolemma. This measurement represented those myoblasts that had proliferated, differentiated, and fused to become differentiated myonuclei during the BrdU-labeling period. The percent of $\mathrm{BrdU}^{+}$myonuclei per total nuclei was lower in BF $(P<0.05)$, TA $(P<0.0005)$, and FDS $(P<0.05)$ IUGR muscle compared to CON (Fig. 2C). Similarly, the number of $\mathrm{BrdU}^{+}$myonuclei per myofiber cross-section was lower in BF $(P<0.005)$, TA $(P<0.0005)$, and FDS $(P<0.005)$ IUGR muscle compared to CON (Fig. 2D).

Myonuclear number, or the total number of myonuclei per myofiber cross-section, was lower in $\mathrm{BF}(P<0.05)$ and FDS $(P<0.05)$ IUGR muscles, respectively, compared to CON, but not the TA (Fig. 2E). The ratio of myonuclei to total nuclei was similar between IUGR and CON groups for all muscles (BF: $0.29 \pm 0.02$ IUGR, $0.29 \pm 0.02 \mathrm{CON}$; TA: $0.28 \pm 0.02$ IUGR, $0.26 \pm 0.02$ CON; FDS: $0.24 \pm 0.01$ IUGR, $0.28 \pm 0.02 \mathrm{CON}$ ), indicating that the numbers of myonuclei were reduced to a similar degree as other nuclei within IUGR muscle.

\section{Myofiber number and size}

Total myofiber number across the entire FDS mid-belly was $32 \%$ lower in IUGR compared to CON $(P<0.005)$ (Fig. 3B). Total area of the section that was composed of

(C) 2020 Society for Endocrinology Published by Bioscientifica Ltd. Printed in Great Britain myofibers and average myofiber cross-sectional area were lower by 57 and 37\%, respectively, in IUGR compared to CON $(P<0.005)$ (Fig. $3 \mathrm{C}$ and D). The myonuclear domain, or the cytoplasmic area per myonucleus, was similar between groups (IUGR: $572 \pm 58$ vs CON: $667 \pm 66 \mu \mathrm{m}^{2}$ ).

\section{Relationships between circulating hormone concentrations and myogenesis rates}

Fetal plasma circulating growth factors insulin and IGF-1 correlated positively and norepinephrine correlated negatively with both the number of $\mathrm{BrdU}^{+}$myonuclei per myofiber and total myofiber number in the FDS muscle $(P<0.01 ;$ Fig. 4A and B). Fetal plasma cortisol concentrations correlated negatively with $\mathrm{BrdU}^{+}$myonuclei $(r=-0.57$, $P<0.01$ ), but were not associated with myofiber number. Similar relationships were observed in the BF and TA muscles between the number of $\mathrm{BrdU}^{+}$myonuclei and insulin concentrations (BF: $r=0.62, P<0.005$; TA: $r=0.64$, $P<0.005$ ), IGF- 1 concentrations (BF: $r=0.65, P<0.005$; TA: $r=0.67, P<0.005)$, and norepinephrine concentrations (BF: $r=-0.64, P<0.005$; TA: $r=-0.73, P<0.0005)$.

\section{Expression of mRNA and proteins related to cell cycle progression, apoptosis, and myogenesis}

The relative expression levels of mRNA and proteins that regulate cell cycle activity and myoblast differentiation 
A

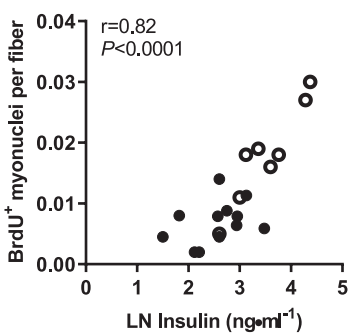

LN Insulin (ng॰ml ${ }^{-1}$ )

B

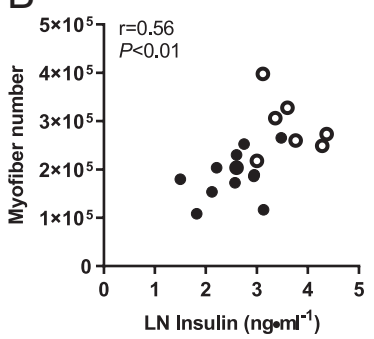

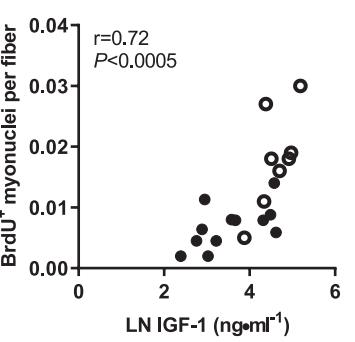

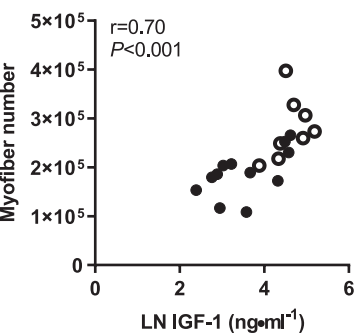

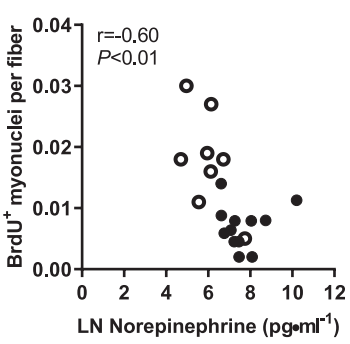

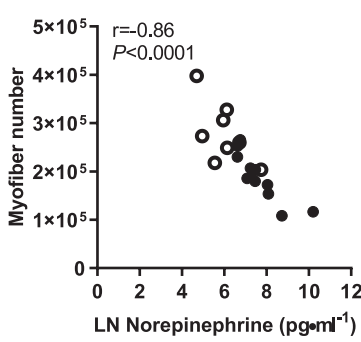

\section{Figure 4}

Correlations between circulating plasma hormones and indices of myogenesis in the flexor digitorum superficialis muscle. Fetal plasma insulin, IGF-1, and norepinephrine are correlated with (A) BrdU+ myonuclei and (B) myofiber number. IUGR fetuses (closed circles, $n=12$ ) and CON fetuses (open circles, $n=8$ ) with correlation coefficients and $P$ values are shown. The natural log for hormone concentrations was used for analysis. in IUGR and CON muscle biopsies are shown in Fig. 5. The mRNA and protein expression of RBL2 (p130), which is a marker of cells in G0 phase of the cell cycle, was similar between IUGR and CON groups (Fig. 5A and F). mRNA expression levels of the cyclins CCNDA2, CCNDB1, CCNDB2, and CCNDE2, and the cyclindependent protein kinases CDK1, CDK4, and CDK6, were lower in IUGR compared to CON $(P<0.05)$, but expression levels of $C C N D 1$ and $C D K 2$ were similar between groups (Fig. 5A). Of the cell cycle inhibitors evaluated, CDKN1A (encoding p21) expression was two-fold higher in IUGR compared to CON $(P<0.05$; Fig. 5B). However, total nuclear protein level of p21 was similar between groups (Fig. 5F). mRNA expression levels of genes that function to activate apoptosis were either similar (BCL2, BAX, APAF, CASP9) or lower in IUGR compared to CON (BAD, CASP3, CASP8; $P<0.05$ ) (Fig. 5C). Pro-caspase 3 protein expression was similar between groups and the cleaved caspase 3 product was not detectable for either group (Fig. 5F). mRNA expression levels of the muscle regulatory factors MYOD, MYF6, and MYOG were lower in IUGR compared to $\mathrm{CON}(P<0.05)$, though expression levels of $P A X 7$ and MYF5 were similar between groups (Fig. 5D). Expression of MSTN, a negative regulator of skeletal muscle growth, was lower in IUGR versus CON $(P<0.05)$ and expression of FST, an inhibitor of MSTN and thus an activator of muscle growth, was similar between groups (Fig. 5D). Expression of FDNC5 (encoding the pro-myogenic factor irisin) was reduced by $44 \%$ in IUGR compared to CON muscle $(P<0.005$; Fig. 5D). Printed in Great Britain

\section{Discussion}

This study demonstrates that in IUGR fetuses, reduced rates of myogenesis in vivo produced fewer numbers of myonuclei and myofibers, which would contribute to smaller muscle mass. By identifying BrdU+ myonuclei within the sarcolemma of the myofiber, we demonstrated that fewer myoblasts had proliferated, differentiated, and fused to form myonuclei during the BrdU labeling period in IUGR muscle compared to normally-growing controls. Expression levels of the muscle regulatory transcription factors MYOD, MYF6 and MYOG were lower in IUGR muscle, as was the expression of FNDC5 (encoding the myokine irisin), further indicating down-regulation of the myogenic program in IUGR skeletal muscle. The proliferation, differentiation, and fusion of satellite cells is an essential regulator of muscle fiber growth by hypertrophy (White et al. 2010, Blaauw \& Reggiani 2014, Egner et al. 2016, Snijders et al. 2016, Dungan et al. 2019); thus, reduced myonuclear accumulation likely contributed to lower muscle weights and myofiber area. Total myofiber number also was lower in the IUGR fetus, indicating that reductions in myogenesis occur as early as mid-gestation when the bulk of secondary myofibers are formed. The mRNA expression levels of nearly all cyclins and CDKs that regulate cell cycle transition points were markedly reduced and markers of apoptosis were not increased in IUGR muscle biopsies, indicating that lower cell cycle activity as opposed to increased rates of apoptosis may have contributed to lower muscle mass. BrdU+ myonuclei and myofiber number in CON and IUGR fetal muscle were 

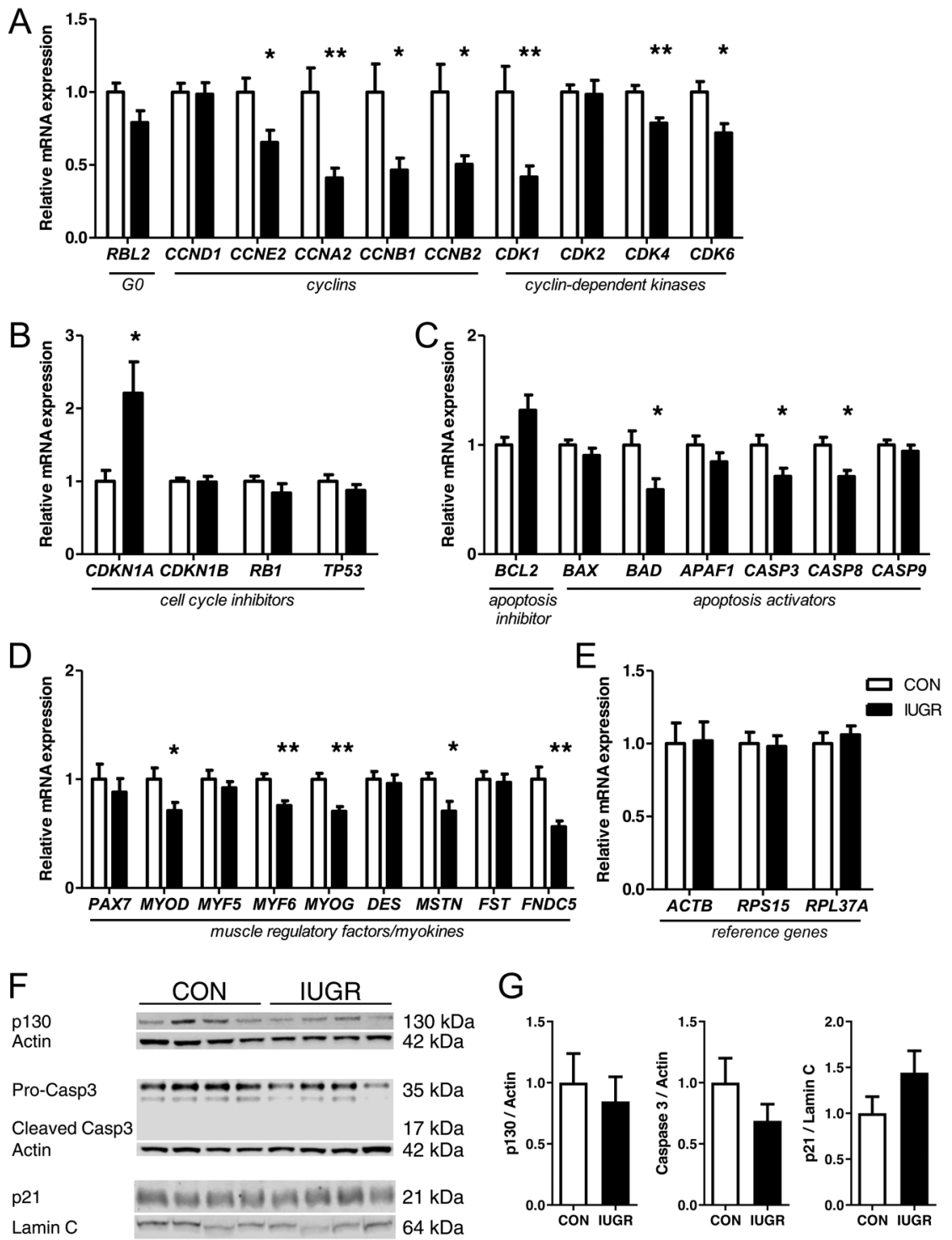

\begin{abstract}
Figure 5
Fetal skeletal muscle mRNA and protein expression. mRNA expression of (A) cell cycle regulators, (B) cell cycle inhibitors, (C) apoptosis regulators, (D) muscle regulatory factors, $(E)$ reference genes; and (F) representative Western blots and densitometry analysis of protein expression p130, caspase 3, and nuclear p21 from CON (white bar, $n=8$ ) and IUGR (black bar, $n=13$ ) fetal biceps femoris muscle. Values represent mean \pm S.E.M. $* P<0.05, * * P<0.005$ by Student's $t$-test.
\end{abstract}

positively correlated with circulating fetal plasma insulin and IGF-1 concentrations, and negatively correlated with norepinephrine concentrations, suggesting a role for hormones in the regulation of myogenesis in the fetus.

BrdU is a thymidine analog that is selectively incorporated into cellular DNA during the synthesis (S) phase of the cell cycle. Despite IUGR fetuses receiving a higher dose of BrdU per kg than control fetuses, they had a lower BrdU labeling index, indicating that the dose of $\sim 40 \mathrm{mg} / \mathrm{kg}$ (20 mg/kg/dose) used in these studies was a flooding dose, given in excess of DNA synthesis rates. An alternative possibility is that the higher relative dose of BrdU given to IUGR fetuses inhibited cellular proliferation, as BrdU has been shown to inhibit myogenesis in vitro (Lawson-Smith \& McGeachie 1998) and embryonic neurogenesis in vivo (Sekerkova et al. 2004). However, it is unlikely that the slightly, albeit statistically, higher cumulative dose of BrdU given to IUGR versus control fetuses ( $\sim 6 \mathrm{mg} / \mathrm{kg}$ versus $\sim 36 \mathrm{mg} / \mathrm{kg}$, respectively) inhibited cell proliferation because both doses were within reported BrdU dosing ranges for pregnant animals to evaluate myogenesis in vivo (Greenwood et al. 1999b, Gokulakrishnan et al. 2017) and much lower than those doses that exceeded $100 \mathrm{mg} / \mathrm{kg}$ previously shown to inhibit neurogenesis (Sekerkova et al. 2004, Taupin 2007, Hancock et al. 2009).

The extent to which specific deficits in myoblast proliferation versus the capacity of the myoblast to differentiate and/or fuse into the myofiber were not distinguished in this study. However, previous work indicates that reduced myoblast proliferation is a likely driver for reduced rates of myogenesis in IUGR. 
We previously showed that in placental insufficiency induced by maternal heat exposure, IUGR fetal skeletal muscle had fewer Pax7+ myoblasts that expressed Ki-67, a marker of cell proliferation (Soto et al. 2017). In the same IUGR model, fewer Pax7+ myoblasts expressed both PCNA and myogenin, indicating fewer differentiated myonuclei as a result of reduced myoblast proliferation (Yates et al. 2014). Further evidence for the suppression of fetal myoblast proliferation as a result of placental insufficiency was shown in sheep bred to produce litters of multiple lambs of variable birthweight. Muscles collected from low-birth-weight lambs in these studies demonstrated less muscle DNA and fewer nuclei entering S phase compared to larger lambs (Greenwood et al. 1999a, 2000). In a rat model of fetal growth restriction induced by exposure of the fetus to maternal glucocorticoids, lower numbers of $\mathrm{BrdU}^{+}$myonuclei per myofiber and Pax7+ myoblasts were demonstrated (Gokulakrishnan et al. 2017). Lower expression of muscle regulatory factors MYOD, MYF6 and MYOG in IUGR muscle in the present study, which are transcription factors expressed in a sequential manner during the differentiation process (Braun \& Gautel 2011), could be the direct result of reduced myonuclear accumulation from lower myoblast proliferation rates, or could be the result of intrinsic defects in the capacity for differentiation. Muscle-specific fusion proteins also have been identified that regulate the fusion process independent of differentiation (Sampath et al. 2018), which are yet to be explored in this model. Taken together, these results demonstrate that rates of myogenesis are exquisitely sensitive to conditions that produce IUGR; whether there are intrinsic deficits in differentiation and/or fusion capacity of the myocyte require further study.

Interestingly, we found reduced mRNA expression of FNDC5 that encodes for irisin in IUGR fetal muscle. Irisin is a myokine that was first demonstrated to induce the expression of genes that result in non-shivering thermogenesis and enhance the browning of white adipose tissue (Bostrom et al. 2012). In addition, irisin has been shown to induce myogenic differentiation and stimulate muscle growth by activating myoblast proliferation, fusion and protein synthesis in both murine and human myotubes (Reza et al. 2017). Cord blood irisin concentrations have been shown to positively correlate with birth weight (Joung et al. 2015) and are lower in IUGR pregnancies (Caglar et al. 2014, Baka et al. 2015). Whether reductions in circulating irisin concentrations are a result of reduced muscle mass or reduced expression of irisin in the IUGR fetus, or how irisin might be involved in the pathogenesis of impaired muscle development in IUGR is yet to be determined.

The addition of myonuclei, either during early development or later in life through the activation of satellite cells, is a key component of the hypertrophic process (Blaauw \& Reggiani 2014). In the present study, myonuclear number, or the number of myonuclei per myofiber cross-section, was reduced in IUGR. Myonuclear number reflects the cumulative history of myonuclear accumulation during muscle development (Amthor et al. 2009), indicating that lower rates of fetal myogenesis are long standing in this model of IUGR. The reduction in myonuclear accumulation paralleled the reduction in the cytoplasmic area of the myofiber, as shown by similar myonuclear domains between CON and IUGR groups. In adult muscle, the myonuclear domain size is relatively constant under most physiological conditions (Allen et al. 1999), including in the hypertrophic response to mechanical overload (Egner et al. 2016) and after prolonged exercise training (Snijders et al. 2016). There are some conditions where hypertrophic growth exceeds the addition of myonuclei, resulting in an increased myonuclear domain, as previously demonstrated in myostatin-knockout mice (Amthor et al. 2009), models of overexpression of protein kinase B (Akt) (Blaauw \& Reggiani 2014), and in mice during early postnatal life (White et al. 2010). However, in the case of the late gestation IUGR fetus, reductions in the cellularity and cytoplasmic area of the IUGR myofiber occur to similar degrees.

The sheep model used in this study is one of early, progressive, and severe placental insufficiency with evidence of fetal hypoxemia and growth restriction early in gestation (Arroyo et al. 2008). Thus, in this model, nutrient and oxygen restriction to the fetus occurs concurrently with the period of secondary myogenesis, which produces the majority of myofibers (Du et al. 2010, Lee et al. 2013). When the entire cross-section of the FDS muscle mid-belly was examined, total myofiber number was lower in IUGR compared to CON. The finding of fewer myofibers in IUGR offspring also has been reported when maternal undernutrition is initiated during early gestation in sheep and other animals. For example, when pregnant sheep were diet restricted by $50 \%$ during early and midgestation, fetal myofiber number was reduced by late gestation and remained lower at 8 months of age (Zhu et al. $2004,2006)$. In pregnant rat dams receiving $30 \%$ of an ad libitum diet during gestation, secondary myofiber number within the fetal soleus and lumbrical muscles was reduced (Wilson et al. 1988). Guinea piglets born to mothers who 
had a $40 \%$ reduction in feed intake during the peak period of secondary myofiber formation had fewer myofibers within glycolytic muscle types (Dwyer \& Stickland 1992, Dwyer et al. 1995). Muscle fiber density, however, was previously shown to be similar between control and IUGR fetal sheep in an ovine model of placental insufficiency (Yates et al. 2014). Thus, the phenotype of the IUGR fetus includes fewer bundles of fibers with similar amounts of connective tissue. Given that there is minimal increase in myofiber number postnatally (Rowe \& Goldspink 1969, Widdowson et al. 1972, White et al. 2010), a reduction in total myofiber number in the fetus potentially limits attainment of normal skeletal muscle mass in adulthood.

Previously, we reported that cell cycle regulation was one of the primary pathways affected by IUGR in fetal skeletal muscle (Soto et al. 2017). In the present study, we found that expression levels of several CDKs and cyclins that regulate each of the transition points in the cell cycle, including first gap (G1) to $S$ phase, $S$ to second gap phase (G2), and G2 to mitosis (M), were downregulated in IUGR $\mathrm{BF}$ muscle biopsies. These results are consistent with an overall reduction of cellular proliferation in the IUGR muscle as demonstrated by a lower BrdU labeling index. Both mRNA and protein expression levels of RBL2 (p130), a G0 marker, were not upregulated in IUGR muscle, arguing against cell cycle arrest in G0. Regulators of apoptosis, including $B A X, B A D, A P A F 1$, and CASP 3, 8, and 9 were not upregulated in IUGR muscle. In addition, there was no difference in protein expression of pro-caspase 3 and the cleaved caspase 3 product was not present in either group. While apoptosis has been implicated in the reduction of myonuclear number in adults under conditions of disuse resulting in muscle atrophy (Siu 2009, Calvani et al. 2013), it does not appear that increased rates of cell death is a factor contributing to lower muscle mass in IUGR.

Circulating fetal plasma insulin and IGF-1 concentrations were positively correlated and norepinephrine, a suppressor of insulin secretion in the fetus (Limesand \& Rozance 2017), was negatively correlated with both the number of $\mathrm{BrdU}^{+}$myonuclei per myofiber and myofiber number. Insulin has been shown to play an important anabolic role in regulating fetal skeletal muscle growth via the PI3 kinase/Akt signaling pathway (Brown et al. 2009, Rhoads et al. 2016, Soto et al. 2017). Similarly, IGF-1 is mitogenic and has been shown to regulate both prenatal and postnatal skeletal muscle growth and regeneration (Liu et al. 1993, PowellBraxton et al. 1993, Ten Broek et al. 2010) and to increase satellite cell proliferation (Chakravarthy et al. 2000). The regulation of myogenesis by IGF-1, however, is highly complex, as both proliferation and differentiation are stimulated through the same IGFR1 receptor (Rosenthal \& Cheng 1995) and IGF-1 has been shown to promote muscle cell survival during myogenic differentiation through Akt-mediated induction of p21 (Lawlor \& Rotwein 2000). p21 is a cyclin-dependent kinase inhibitor that arrests cell cycle progression in G1/S by associating with CDKs 2, 4, and 6, and cyclins D and E (Karimian et al. 2016). p21 is integral to myogenic differentiation (Guo et al. 1995) and can be regulated at transcriptional, post-transcriptional, and post-translational levels (Jung et al. 2010). We found an increase in CDNK1A mRNA expression but no increase in the active nuclear protein product p21 in IUGR muscle biopsies. Further studies are required to determine whether the downregulation of several cell cycle regulators is a mechanism via which lower concentrations of insulin and IGF-1 may reduce myoblast proliferation and/or the proliferation of other cell types within fetal muscle, or whether lower expression of several cyclins and CDKs, which can still be expressed in terminally differentiated myonuclei (Guo et al. 1995), simply reflects lower myonuclear number in IUGR muscle.

A limitation of this study was that mRNA and protein analyses were performed on whole muscle biopsies, which contain several cell types. The BrdU labeling index was lower in IUGR muscle, demonstrating that the reduction in proliferation rates likely affected many cell types within muscle, in addition to myonuclei, which make up about $25 \%$ of all nuclei in both CON and IUGR fetal muscle. Future studies using immunohistochemistry, flow cytometry, or other methods will be required to specifically identify cell type (e.g., fibroblasts, vascular cells, endothelial cells, and macrophages), along with exploration of the mechanisms that result in impairments in cellular proliferation in IUGR fetal skeletal muscle. Additionally, sex is known to affect fetal growth, with males being larger than females (Wallace et al. 2018). Testing for the effect of sex in the current study was limited due to lack of power to identify potential interactions between IUGR and sex. Investigation as to whether IUGR affects male and female skeletal muscle growth differently will be important for future studies. Finally, three different muscles were used from the fetal hindlimb for analysis, and there were minor differences in BrdU incorporation and myonuclear number among muscles. It is possible that skeletal muscles collected from different sites (forelimbs, diaphragm, lumbricals) might demonstrate different myogenic responses to placental insufficiency. 
The timing of onset and severity of IUGR will have important implications for the growth potential of muscle postnatally. The sheep model used for these studies is one of long-standing and severe placental insufficiency that mimics 'early' human IUGR with onset $<32$ weeks gestation, as opposed to more mildly affected 'late' IUGR pregnancies (Savchev et al. 2014, Figueras et al. 2015). If the onset of oxygen and nutrient restriction occurs at the peak of myoblast proliferation and fusion to form myotubes, the likelihood of reductions in myonuclear and myofiber number will be greater (Fahey et al. 2005a,b). Fewer total myofibers established during gestation is likely one of the reasons why low birth weight from IUGR strongly predicts muscle mass later in adulthood (Brown \& Hay 2016). Lower myonuclear numbers in IUGR fetal muscle at birth also might limit postnatal hypertrophic muscle growth. Muscle fiber diameter in growing animals has been directly correlated with myonuclear number (Allen et al. 1979), consistent with the concept of an upper limit in the myonuclear domain size or amount of cytoplasm that each myonucleus can support (Petrella et al. 2006). In 'late' occurring IUGR, however, we speculate that myofiber and myonuclear number may remain intact with the potential for compensatory postnatal hypertrophy (Prakash et al. 1993, Fahey et al. 2005a). Further evaluation into the consequences of reduced rates of myogenesis during fetal life and the impact on postnatal muscle growth capacity is warranted.

\section{Declaration of interest}

The authors declare that there is no conflict of interest that could be perceived as prejudicing the impartiality of the research reported.

\section{Funding}

L D B was supported by NIH R01-HD079404 and The Center for Women's Health Research at the University of Colorado School of Medicine. P J R was supported by NIH R01-DK088139 and R01-HD093701. W W H was supported by NIH T32-HD007186 and K12-HD068372. S R W was supported by NIH R01-DK108910.

\section{References}

Allen RE, Merkel RA \& Young RB 1979 Cellular aspects of muscle growth: myogenic cell proliferation. Journal of Animal Science 49 115-127. (https://doi.org/10.2527/jas1979.491115x)

Allen DL, Roy RR \& Edgerton VR 1999 Myonuclear domains in muscle adaptation and disease. Muscle and Nerve 22 1350-1360. (https://doi.org/10.1002/(sici)1097-4598(199910)22:10<1350::aidmus3>3.0.co;2-8)
Amthor H, Otto A, Vulin A, Rochat A, Dumonceaux J, Garcia L, Mouisel E, Hourde C, Macharia R, Friedrichs M, et al. 2009 Muscle hypertrophy driven by myostatin blockade does not require stem/precursor-cell activity. PNAS 106 7479-7484. (https://doi. org/10.1073/pnas.0811129106)

Arroyo JA, Anthony RV \& Galan HL 2008 Decreased placental X-linked inhibitor of apoptosis protein in an ovine model of intrauterine growth restriction. American Journal of Obstetrics and Gynecology 199 80.e1-80.e8. (https://doi.org/10.1016/j.ajog.2007.12.017)

Baka S, Malamitsi-Puchner A, Boutsikou T, Boutsikou M, Marmarinos A, Hassiakos D, Gourgiotis D \& Briana DD 2015 Cord blood irisin at the extremes of fetal growth. Metabolism: Clinical and Experimental 64 1515-1520. (https://doi.org/10.1016/j.metabol.2015.07.020)

Bell AW, Wilkening RB \& Meschia G 1987 Some aspects of placental function in chronically heat-stressed ewes. Journal of Developmental Physiology 9 17-29.

Benjamin JS, Culpepper CB, Brown LD, Wesolowski SR, Jonker SS, Davis MA, Limesand SW, Wilkening RB, Hay WW. \& Rozance PJ 2017 Chronic anemic hypoxemia attenuates glucose-stimulated insulin secretion in fetal sheep. American Journal of Physiology: Regulatory, Integrative and Comparative Physiology 312 R492-R500. (https://doi. org/10.1152/ajpregu.00484.2016)

Blaauw B \& Reggiani C 2014 The role of satellite cells in muscle hypertrophy. Journal of Muscle Research and Cell Motility 35 3-10. (https://doi.org/10.1007/s10974-014-9376-y)

Bostrom P, Wu J, Jedrychowski MP, Korde A, Ye L, Lo JC, Rasbach KA, Bostrom EA, Choi JH, Long JZ, et al. 2012 A PGC1-alpha-dependent myokine that drives brown-fat-like development of white fat and thermogenesis. Nature 481 463-468. (https://doi.org/10.1038/ nature10777)

Braun T \& Gautel M 2011 Transcriptional mechanisms regulating skeletal muscle differentiation, growth and homeostasis. Nature Reviews: Molecular Cell Biology 12 349-361. (https://doi.org/10.1038/nrm3118)

Brown LD 2014 Endocrine regulation of fetal skeletal muscle growth: impact on future metabolic health. Journal of Endocrinology $\mathbf{2 2 1}$ R13-R29. (https://doi.org/10.1530/JOE-13-0567)

Brown LD \& Hay WW 2016 Impact of placental insufficiency on fetal skeletal muscle growth. Molecular and Cellular Endocrinology 435 69-77. (https://doi.org/10.1016/j.mce.2016.03.017)

Brown LD, Rozance PJ, Barry JS, Friedman JE \& Hay WW 2009 Insulin is required for amino acid stimulation of dual pathways for translational control in skeletal muscle in the late-gestation ovine fetus. American Journal of Physiology: Endocrinology and Metabolism 296 E56-E63. (https://doi.org/10.1152/ajpendo.90310.2008)

Brown LD, Rozance PJ, Thorn SR, Friedman JE \& Hay WW 2012 Acute supplementation of amino acids increases net protein accretion in IUGR fetal sheep. American Journal of Physiology: Endocrinology and Metabolism 303 E352-E364. (https://doi.org/10.1152/ ajpendo.00059.2012)

Brown LD, Wesolowski SR, Kailey J, Bourque S, Wilson A, Andrews SE, Hay WW. \& Rozance PJ 2016 Chronic hyperinsulinemia increases myoblast proliferation in fetal sheep skeletal muscle. Endocrinology 157 2447-2460. (https://doi.org/10.1210/en.2015-1744)

Caglar M, Goksu M, Isenlik BS, Yavuzcan A, Yilmaz M, Ustun Y, Aydin S \& Kumru S 2014 Irisin in idiopathic foetal growth restriction. Journal of Endocrinological Investigation 37 619-624. (https://doi.org/10.1007/ s40618-014-0078-5)

Calvani R, Joseph AM, Adhihetty PJ, Miccheli A, Bossola M, Leeuwenburgh C, Bernabei R \& Marzetti E 2013 Mitochondrial pathways in sarcopenia of aging and disuse muscle atrophy. Biological Chemistry 394 393-414. (https://doi.org/10.1515/hsz-2012-0247)

Chakravarthy MV, Abraha TW, Schwartz RJ, Fiorotto ML \& Booth FW 2000 Insulin-like growth factor-I extends in vitro replicative life span of skeletal muscle satellite cells by enhancing G1/S cell cycle progression via the activation of phosphatidylinositol 3'-kinase/Akt https://joe.bioscientifica.com

https://doi.org/10.1530/JOE-19-0273 (c) 2020 Society for Endocrinology Published by Bioscientifica Ltd. Printed in Great Britain 
signaling pathway. Journal of Biological Chemistry $27535942-35952$. (https://doi.org/10.1074/jbc.M005832200)

Du M, Tong J, Zhao J, Underwood KR, Zhu M, Ford SP \& Nathanielsz PW 2010 Fetal programming of skeletal muscle development in ruminant animals. Journal of Animal Science 88 E51-E60. (https://doi. org/10.2527/jas.2009-2311)

Dungan CM, Murach KA, Frick KK, Jones SR, Crow SE, Englund DA, Vechetti IJ, Figueiredo VC, Levitan BM, Satin J, et al. 2019 Elevated myonuclear density during skeletal muscle hypertrophy in response to training is reversed during detraining. American Journal of Physiology: Cell Physiology 316 C649-C654. (https://doi.org/10.1152/ ajpcell.00050.2019)

Dwyer CM \& Stickland NC 1992 Does the anatomical location of a muscle affect the influence of undernutrition on muscle fibre number? Journal of Anatomy 181 373-376.

Dwyer CM, Madgwick AJ, Ward SS \& Stickland NC 1995 Effect of maternal undernutrition in early gestation on the development of fetal myofibres in the guinea-pig. Reproduction, Fertility, and Development 7 1285-1292. (https://doi.org/10.1071/rd9951285)

Egner IM, Bruusgaard JC \& Gundersen K 2016 Satellite cell depletion prevents fiber hypertrophy in skeletal muscle. Development 143 2898-2906. (https://doi.org/10.1242/dev.134411)

Fahey AJ, Brameld JM, Parr T \& Buttery PJ 2005a The effect of maternal undernutrition before muscle differentiation on the muscle fiber development of the newborn lamb. Journal of Animal Science $\mathbf{8 3}$ 2564-2571. (https://doi.org/10.2527/2005.83112564x)

Fahey AJ, Brameld JM, Parr T \& Buttery PJ 2005b Ontogeny of factors associated with proliferation and differentiation of muscle in the ovine fetus. Journal of Animal Science 83 2330-2338. (https://doi. $\operatorname{org} / 10.2527 / 2005.83102330 \mathrm{x}$ )

Figueras F, Savchev S, Triunfo S, Crovetto F \& Gratacos E 2015 An integrated model with classification criteria to predict small-forgestational-age fetuses at risk of adverse perinatal outcome. Ultrasound in Obstetrics and Gynecology 45 279-285. (https://doi.org/10.1002/ uog.14714)

Galan HL, Hussey MJ, Barbera A, Ferrazzi E, Chung M, Hobbins JC \& Battaglia FC 1999 Relationship of fetal growth to duration of heat stress in an ovine model of placental insufficiency. American Journal of Obstetrics and Gynecology 180 1278-1282. (https://doi.org/10.1016/ s0002-9378(99)70629-0)

Gokulakrishnan G, Chang X, Fleischmann R \& Fiorotto ML 2017 Precocious glucocorticoid exposure reduces skeletal muscle satellite cells in the fetal rat. Journal of Endocrinology 232 561-572. (https:// doi.org/10.1530/JOE-16-0372)

Greenwood PL, Slepetis RM, Bell AW \& Hermanson JW 1999a Intrauterine growth retardation is associated with reduced cell cycle activity, but not myofibre number, in ovine fetal muscle. Reproduction, Fertility and Development 11 281-291. (https://doi.org/10.1071/ RD99054)

Greenwood PL, Slepetis RM, Hermanson JW \& Bell AW 1999b An ultrasound-guided procedure to administer a label of DNA synthesis into fetal sheep. Reproduction, Fertility, and Development 11 303-307. (https://doi.org/10.1071/rd99053)

Greenwood PL, Hunt AS, Hermanson JW \& Bell AW 2000 Effects of birth weight and postnatal nutrition on neonatal sheep: II. Skeletal muscle growth and development. Journal of Animal Science 78 50-61. (https:// doi.org/10.2527/2000.78150x)

Guo K, Wang J, Andres V, Smith RC \& Walsh K 1995 MyoD-induced expression of p21 inhibits cyclin-dependent kinase activity upon myocyte terminal differentiation. Molecular and Cellular Biology 15 3823-3829. (https://doi.org/10.1128/mcb.15.7.3823)

Hancock A, Priester C, Kidder E \& Keith JR 2009 Does 5-bromo2 '-deoxyuridine (BrdU) disrupt cell proliferation and neuronal maturation in the adult rat hippocampus in vivo? Behavioural Brain Research 199 218-221. (https://doi.org/10.1016/j.bbr.2008.11.050)
Herdrich BJ, Danzer E, Davey MG, Allukian M, Englefield V, Gorman 3rd JH, Gorman RC \& Liechty KW 2010 Regenerative healing following foetal myocardial infarction. European Journal of Cardio-Thoracic Surgery 38 691-698. (https://doi.org/10.1016/j.ejcts.2010.03.049)

Joung KE, Park KH, Filippaios A, Dincer F, Christou H \& Mantzoros CS 2015 Cord blood irisin levels are positively correlated with birth weight in newborn infants. Metabolism: Clinical and Experimental 64 1507-1514. (https://doi.org/10.1016/j.metabol.2015.07.019)

Jung YS, Qian Y \& Chen X 2010 Examination of the expanding pathways for the regulation of p21 expression and activity. Cellular Signalling 22 1003-1012. (https://doi.org/10.1016/j.cellsig.2010.01.013)

Karimian A, Ahmadi Y \& Yousefi B 2016 Multiple functions of p21 in cell cycle, apoptosis and transcriptional regulation after DNA damage. DNA Repair 42 63-71. (https://doi.org/10.1016/j. dnarep.2016.04.008)

Lawlor MA \& Rotwein P 2000 Insulin-like growth factor-mediated muscle cell survival: central roles for Akt and cyclin-dependent kinase inhibitor p21. Molecular and Cellular Biology 20 8983-8995. (https:// doi.org/10.1128/mcb.20.23.8983-8995.2000)

Lawson-Smith MJ \& McGeachie JK 1998 The identification of myogenic cells in skeletal muscle, with emphasis on the use of tritiated thymidine autoradiography and desmin antibodies. Journal of Anatomy 192 161-171. (https://doi.org/10.1046/j.14697580.1998.19220161.x)

Lee AS, Harris J, Bate M, Vijayraghavan K, Fisher L, Tajbakhsh S \& Duxson M 2013 Initiation of primary myogenesis in amniote limb muscles. Developmental Dynamics 242 1043-1055. (https://doi. org/10.1002/dvdy.23998)

Limesand SW \& Rozance PJ 2017 Fetal adaptations in insulin secretion result from high catecholamines during placental insufficiency. Journal of Physiology 595 5103-5113. (https://doi.org/10.1113/ JP273324)

Liu JP, Baker J, Perkins AS, Robertson EJ \& Efstratiadis A 1993 Mice carrying null mutations of the genes encoding insulin-like growth factor I (Igf-1) and type 1 IGF receptor (Igf1r). Cell 75 59-72. (https:// doi.org/10.1016/S0092-8674(05)80084-4)

Moss FP \& Leblond CP 1971 Satellite cells as the source of nuclei in muscles of growing rats. Anatomical Record 170 421-435. (https://doi. org/10.1002/ar.1091700405)

Padoan A, Rigano S, Ferrazzi E, Beaty BL, Battaglia FC \& Galan HL 2004 Differences in fat and lean mass proportions in normal and growthrestricted fetuses. American Journal of Obstetrics and Gynecology 191 1459-1464. (https://doi.org/10.1016/j.ajog.2004.06.045)

Petrella JK, Kim JS, Cross JM, Kosek DJ \& Bamman MM 2006 Efficacy of myonuclear addition may explain differential myofiber growth among resistance-trained young and older men and women. American Journal of Physiology: Endocrinology and Metabolism 291 E937-E946. (https://doi.org/10.1152/ajpendo.00190.2006)

Powell-Braxton L, Hollingshead P, Warburton C, Dowd M, Pitts-Meek S, Dalton D, Gillett N \& Stewart TA 1993 IGF-I is required for normal embryonic growth in mice. Genes and Development 7 2609-2617. (https://doi.org/10.1101/gad.7.12b.2609)

Prakash YS, Fournier M \& Sieck GC 1993 Effects of prenatal undernutrition on developing rat diaphragm. Journal of Applied Physiology 75 1044-1052. (https://doi.org/10.1152/ jappl.1993.75.3.1044)

Reza MM, Subramaniyam N, Sim CM, Ge X, Sathiakumar D, McFarlane C, Sharma M \& Kambadur R 2017 Irisin is a pro-myogenic factor that induces skeletal muscle hypertrophy and rescues denervation-induced atrophy. Nature Communications 8 1104. (https://doi.org/10.1038/ s41467-017-01131-0)

Rhoads RP, Baumgard LH, El-Kadi SW \& Zhao LD 2016 PHYSIOLOGY AND ENDOCRINOLOGY SYMPOSIUM: Roles for insulin-supported skeletal muscle growth. Journal of Animal Science 94 1791-1802. (https://doi.org/10.2527/jas.2015-0110) https://joe.bioscientifica.com

https://doi.org/10.1530/JOE-19-0273 (c) 2020 Society for Endocrinology Published by Bioscientifica Ltd. Printed in Great Britain 
Rosenthal SM \& Cheng ZQ 1995 Opposing early and late effects of insulin-like growth factor I on differentiation and the cell cycle regulatory retinoblastoma protein in skeletal myoblasts. PNAS 92 10307-10311. (https://doi.org/10.1073/pnas.92.22.10307)

Rowe RW \& Goldspink G 1969 Muscle fibre growth in five different muscles in both sexes of mice. Journal of Anatomy 104 519-530.

Rozance PJ, Zastoupil L, Wesolowski SR, Goldstrohm DA, Strahan B, Cree-Green M, Sheffield-Moore M, Meschia G, Hay WW, Wilkening RB, et al. 2018 Skeletal muscle protein accretion rates and hindlimb growth are reduced in late gestation intrauterine growthrestricted fetal sheep. Journal of Physiology 596 67-82. (https://doi. org/10.1113/JP275230)

Sampath SC, Sampath SC \& Millay DP 2018 Myoblast fusion confusion: the resolution begins. Skeletal Muscle 8 3. (https://doi.org/10.1186/ s13395-017-0149-3)

Savchev S, Figueras F, Sanz-Cortes M, Cruz-Lemini M, Triunfo S, Botet F \& Gratacos E 2014 Evaluation of an optimal gestational age cut-off for the definition of early- and late-onset fetal growth restriction. Fetal Diagnosis and Therapy 36 99-105. (https://doi. org/10.1159/000355525

Sekerkova G, Ilijic E \& Mugnaini E 2004 Bromodeoxyuridine administered during neurogenesis of the projection neurons causes cerebellar defects in rat. Journal of Comparative Neurology 470 221-239. (https://doi.org/10.1002/cne.11016)

Shah B, Hyde-Dunn J \& Jones GE 1997 Proliferation of murine myoblasts as measured by bromodeoxyuridine incorporation. Methods in Molecular Biology 75 349-355. (https://doi.org/10.1385/0-89603-441$0: 349)$

Siu PM 2009 Muscle apoptotic response to denervation, disuse, and aging. Medicine and Science in Sports and Exercise 41 1876-1886. (https://doi.org/10.1249/MSS.0b013e3181a6470b)

Snijders T, Smeets JS, Van Kranenburg J, Kies AK, Van Loon LJ \& Verdijk LB 2016 Changes in myonuclear domain size do not precede muscle hypertrophy during prolonged resistance-type exercise training. Acta Physiologica 216 231-239. (https://doi.org/10.1111/ apha.12609)

Soto SM, Blake AC, Wesolowski SR, Rozance PJ, Barthel KB, Gao B, Hetrick B, Mccurdy CE, Garza NG, Hay WW, et al. 2017 Myoblast replication is reduced in the IUGR fetus despite maintained proliferative capacity in vitro. Journal of Endocrinology 232 475-491. (https://doi.org/10.1530/JOE-16-0123)

Taupin P 2007 BrdU immunohistochemistry for studying adult neurogenesis: paradigms, pitfalls, limitations, and validation. Brain Research Reviews 53 198-214. (https://doi.org/10.1016/j. brainresrev.2006.08.002)
Ten Broek RW, Grefte S \& Von Den Hoff JW 2010 Regulatory factors and cell populations involved in skeletal muscle regeneration. Journal of Cellular Physiology 224 7-16. (https://doi.org/10.1002/ jcp.22127)

Wallace JM, Milne JS, Aitken RP, Horgan GW \& Adam CL 2018 Ovine prenatal growth restriction impacts glucose metabolism and body composition throughout life in both sexes. Reproduction 156 103-119. (https://doi.org/10.1530/REP-18-0048)

White RB, Bierinx AS, Gnocchi VF \& Zammit PS 2010 Dynamics of muscle fibre growth during postnatal mouse development. BMC Developmental Biology 10 21. (https://doi.org/10.1186/1471213X-10-21)

Widdowson EM, Crabb DE \& Milner RD 1972 Cellular development of some human organs before birth. Archives of Disease in Childhood $\mathbf{4 7}$ 652-655. (https://doi.org/10.1136/adc.47.254.652)

Wigmore PM \& Stickland NC 1983 Muscle development in large and small pig fetuses. Journal of Anatomy 137 235-245.

Wilson SJ, Ross JJ \& Harris AJ 1988 A critical period for formation of secondary myotubes defined by prenatal undernourishment in rats. Development 102 815-821.

Yates DT, Clarke DS, Macko AR, Anderson MJ, Shelton LA, Nearing M, Allen RE, Rhoads RP \& Limesand SW 2014 Myoblasts from intrauterine growth-restricted sheep fetuses exhibit intrinsic deficiencies in proliferation that contribute to smaller semitendinosus myofibres. Journal of Physiology 592 3113-3125. (https://doi. org/10.1113/jphysiol.2014.272591)

Yates DT, Cadaret CN, Beede KA, Riley HE, Macko AR, Anderson MJ, Camacho LE \& Limesand SW 2016 Intrauterine growthrestricted sheep fetuses exhibit smaller hindlimb muscle fibers and lower proportions of insulin-sensitive Type I fibers near term. American Journal of Physiology: Regulatory, Integrative and Comparative Physiology 310 R1020-R1029. (https://doi.org/10.1152/ ajpregu.00528.2015)

Yu M, Wang H, Xu Y, Yu D, Li D, Liu X \& Du W 2015 Insulin-like growth factor-1 (IGF-1) promotes myoblast proliferation and skeletal muscle growth of embryonic chickens via the PI3K/Akt signalling pathway. Cell Biology International 39 910-922. (https://doi.org/10.1002/cbin.10466)

Zhu MJ, Ford SP, Nathanielsz PW \& Du M 2004 Effect of maternal nutrient restriction in sheep on the development of fetal skeletal muscle. Biology of Reproduction 71 1968-1973. (https://doi. org/10.1095/biolreprod.104.034561)

Zhu MJ, Ford SP, Means WJ, Hess BW, Nathanielsz PW \& Du M 2006 Maternal nutrient restriction affects properties of skeletal muscle in offspring. Journal of Physiology 575 241-250. (https://doi.org/10.1113/ jphysiol.2006.112110)

Received in final form 30 October 2019

Accepted 12 November 2019

Accepted Manuscript published online 18 November 2019 https://joe.bioscientifica.com https://doi.org/10.1530/JOE-19-0273
(C) 2020 Society for Endocrinology Published by Bioscientifica Ltd. Printed in Great Britain 